\title{
Bruk av legemidler utenfor godkjent indikasjon
}

\author{
Når et legemiddel brukes på annen måte enn den det er offisielt godkjent for, kalles det på engelsk off label. \\ Vi mener bruk utenfor godkjent indikasjon eller bruk utenfor godkjent preparatomtale er gode betegnelser
} på norsk.

Alle godkjente legemidler i Norge har dokumentasjon som viser effekt for bruksområdet de er godkjent for. Anvendelse utenfor dette området kalles off label-bruk. Myndighetene har da ikke vurdert og godkjent data for denne bruken, som f.eks. til annen sykdom, $i$ annen dose eller i annen aldersgruppe (1).

Dette er ikke uvanlig, bl.a. ved legemiddelbehandling av barn, men det setter større krav til forskrivende lege. Slik bruk må skilles fra bruk av uregistrerte preparater og bruk av legemidler uten markedsføringstillatelse (2).

\section{Indikasjon og preparatomtale}

$\AA$ få godkjent nye indikasjoner for legemidler er en kostbar og tidkrevende prosess, noe som fører til at produsentene i en del tilfeller unnlater å utvide indikasjonsområdet etter hvert som dokumentasjon på effekt ved andre tilstander eller hos nye pasientgrupper kommer til (3). Da må legen forskrive utenfor godkjent indikasjon. Innen flere fagområder er det vanskelig å komme utenom slik forskrivning (3). To av tre barn i sykehus får legemiddelbehandling som på en eller annen måte faller utenfor formelt godkjente bruksområder eller bruksmåter (4).

Off label gir 21 treff i Tidsskriftets nettutgave, første gang i en artikkel fra 2003 (4), og det gir 116 treff i norske artikler i Retriever, en søketjeneste for aviser, tidsskrifter og andre publikasjoner, første gang i 1998 (20.11.2015). Ikke alle treffene i Retriever angår humanmedisinen. Blant relevante treff er det flere interessante forslag til norske oversettelser. Et spørsmål til helseog omsorgsministeren i 2013 handlet om «bruk av legemidler utenfor godkjent indikasjon» (5). Samme løsning har regionale legemiddelinformasjonssentre (Relis) benyttet (6). I Tidsskriftet har vi også registrert en kortere variant: «bruk utenfor indikasjon» (7). Relis har dessuten skrevet om «bruk utenom ordinære godkjenninger» (8), mens Statens legemiddelverk har bl.a. anvendt «Bruk utenfor godkjent bruksområde» (1). Både utenfor og utenom kan brukes som synonymer i disse sammenhengene.

Uttrykket bruk utenfor godkjent indikasjon er i alle fall brukt siden 1990-årene (9). I Retriever gir det 19 treff. Man kan derfor med en viss rett si at det er blitt et etablert uttrykk. Enkelte vil imidlertid oppfatte indikasjon som litt smalt i denne sammenhengen. Man kan derfor heller si bruk utenfor godkjent preparatomtale. Da får man med både indikasjon, alder, kjønn osv. Dette gir ett treff i Retriever. Indikasjon og preparatomtale er ord som ikke nødvendigvis forstås av alle. En annen variant er derfor bruk utenfor godkjent bruksanvisning - hvor bruksanvisning er en folkelig betegnelse på preparatomtale, men det gir ingen treff i Retriever.

Vårt forslag er derfor bruk utenfor godkjent indikasjon eller bruk utenfor godkjent preparatomtale og med «off label» eller «off label-bruk» i parentes bak første gang det nevnes i teksten.

\section{Erlend Hem \\ erlend.hem@medisin.uio.no \\ Steinar Madsen}

Erlend Hem (f. 1970) er dr.med., fagsjef i Klinikk psykisk helse og avhengighet, Oslo universitetssykehus, og redaktør for Tidsskriftets språkspalte.

Steinar Madsen (f. 1956) er medisinsk fagdirektør i Statens legemiddelverk.

\section{Litteratur}

1. Kartlegging av medisinbruk hos barn. Statens legemiddelverk 1.3.2011. Oslo: Statens legemid delverk, 2011

2. Godkjent eller ikke godkjent - hvilke statuser kan et legemiddel ha? Statens legemiddelverk.

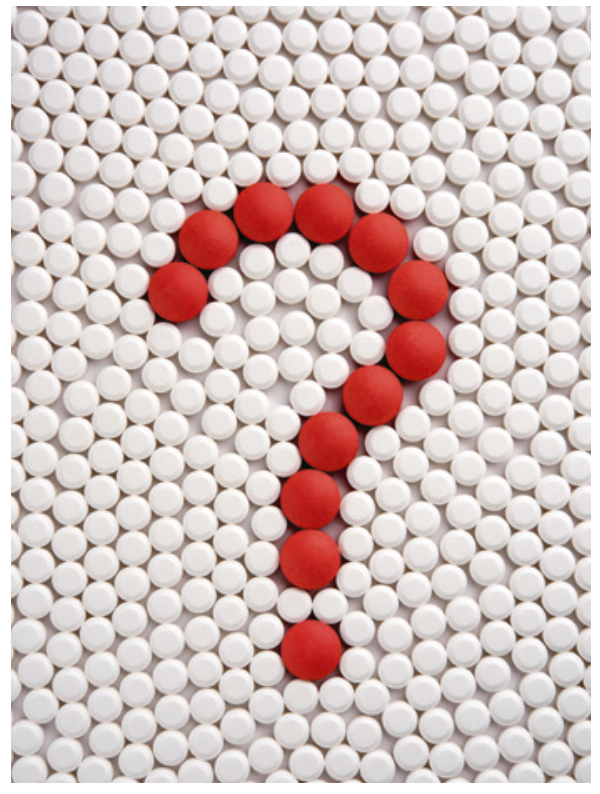

Illustrasjonsfoto: Thinkstock

www.legemiddelverket.no/Godkjenning_og_ regelverk/godkjenning_av_legemidler/ Slik godkjennes legemidter/Sider/Godkjenteller-ikke-godkjent.aspx (20.11.2015).

3. Raknes G. Gamle legemidler, nye muligheter Tidsskr Nor Legeforen 2008; 128: 62-5

4. Kalikstad B, Hansen TW. Medikamentell behandling av nyfødte - et sjansespill? Tidsskr Nor Lægeforen 2003: 123: 2738-40.

5. Skriftlig spørsmål fra Ketil Solvik-Olsen (FrP) til helse- og omsorgsministeren. Stortinget 25.6.2013. www.stortinget.no/no/Saker-ogpublikasjoner/Sporsmal/Skriftlige-sporsmal-ogsvar/Skriftlig-sporsmal/?qid=57790 (20.11.2015).

6. Raknes G, Giverhaug T. Naltrekson - høye forventninger til lave doser. Relis 20.5.2011. www.relis.no/content/3297/Naltrekson---hoyeforventninger-til-lave-doser (20.11.2015).

7. Høeg E, Frostelid T. Systematisk bruk av legemidler utenfor godkjent indikasjon. Tidsskr Nor Legeforen 2010; 130: 1452-3

8. Kalikstad B, Westergren T. Medisiner til barn - når nødløsninger blir rutine. Relis 23.3.2006. www.relis.no/content/2593/Medisiner-til-barn--nar-nodlosninger-blir-rutine (20.11.2015).

9. Rygnestad T. Bruk av legemidler utenfor godkjent indikasjon. Tidsskr Nor Lægeforen 1998; 118: 932-3. 